\title{
Persistence in Mice of the L-Phase of Three Streptococcal Strains Adapted to Physiological Osmotic Conditions
}

\author{
By H. A. L. CLASENER, HENRIETTE L. ENSERING \\ AND W. HIJMANS \\ Institute for Rheumatism Research, University Hospital, \\ Leiden, The Netherlands
}

(Accepted for publication 24 April I970)

\begin{abstract}
SUMMARY
Inability of the L-phase of Gram-positive bacteria to persist in vivo is explainable by its need for osmotic protection. Adaptation to physiological osmotic conditions did not enhance the ability of the L-phase to survive in vivo after intravenous or intraperitoneal injection in mice. One 'low-salt' L-strain survived in mice for 8 days in vivo when protected against phagocytosis by a filter box, whereas under the same conditions its 'high-salt' parent L-strain died in a few hours. The decrease of the number of surviving colony-forming units of this low-salt L-strain in the filter box contrasts sharply with the increase in number shown by the parent bacterial strain protected in the same way.
\end{abstract}

\section{INTRODUCTION}

The L-phase of group A streptococcus derives its importance from its being mentioned in considerations about the cause of rheumatic fever (Watson, Hirst \& Lancefield, I96I; McCarty, I964) and also of rheumatoid arthritis (Lack, I968). Isolation from patients of the group A streptococcal L-phase has been claimed (Kagan \& Mikhailova, 1963) as well as the persistence in mice (Schmitt-Slomska, Sacquet \& Caravano, 1967; Schmitt-Slomska \& Mauss, 1968) and in cell cultures (SchmittSlomska, Boué \& Caravano, I968) of an L-phase induced in vitro.

Gram-positive bacteria require strong osmotic protection when in the L-phase and even the growth of the L-phase derived from Gram-negative bacteria generally is better on media with a higher osmotic value than bacteriological media usually have. Therefore the generally observed loss of pathogenicity resulting from the induction of the L-phase is plausibly correlated with the osmotic lability of the L-phase (Hijmans, van Boven \& Clasener, 1969).

To obviate the difficulties of working with strains requiring osmotic protection in an environment which does not offer this protection, several L-phase strains were adapted to grow in physiological conditions. Adaptation in vitro of the L-phase of three Grampositive bacterial strains to physiological conditions did not make their capability to survive in vivo comparable to that of their bacterial phase.

\section{METHODS}

Strains. The L-strains were induced by the use of penicillin from the following three parent strains: group A haemolytic streptococcus strain GL-8, type 19; group A haemolytic streptococcus strain VB, type 6, obtained from Dr H. A. Valkenburg of this 
Institute; and Streptococcus faecalis strain B 9, obtained from Dr L. B. Guze of the Los Angeles School of Medicine, and originally used for producing pyelonephritis in rats (Guze \& Kalmanson, 1964; Clasener \& Ensering, I970a).

Media. Trypticase soy broth dehydrated (Difco) $3 \%$ (w/v) or brucella broth (Albimi) $2.7 \%$ (w/v); ion agar no. 2 (Oxoid) or agar Noble (Difco) I \% (w/v) when solid medium was required; bovine albumin (for bacteriological media, Poviet, Amsterdam) $0.3 \%$ $(\mathrm{w} / \mathrm{v}) ; \mathrm{NaCl} 2 \cdot 2 \%(\mathrm{w} / \mathrm{v}) ;$ yeast extract (Oxoid) $\mathrm{I} \%(\mathrm{w} / \mathrm{v})$. Penicillin was routinely added (1000-1 500 units $/ \mathrm{ml}$.).

\section{Adaptation of L-strains to media not giving the usual osmotic protection}

Recently induced L-strains were first adapted to liquid media by lowering the agar concentration of the successive transfer media. Then the $\mathrm{NaCl}$ concentration in the liquid medium was generally reduced from $3 \%(\mathrm{w} / \mathrm{v})$ to $\mathrm{I} \cdot 2 \%(\mathrm{w} / \mathrm{v})$ in steps of $0 . \mathrm{I} \%$ $(\mathrm{w} / \mathrm{v})$ and thereafter in steps of $0.01 \%(\mathrm{w} / \mathrm{v})$ at each transfer until a final concentration in the medium of $0.9 \%(\mathrm{w} / \mathrm{v}) \mathrm{NaCl}$ was reached. On the basis of one sodium determination of the trypticase soy broth we assumed the $\mathrm{NaCl}$ concentration to be $0.78 \%(\mathrm{w} / \mathrm{v})$; therefore we considered the strains to be adapted to physiological osmotic conditions when not more than $0.2 \%(\mathrm{w} / \mathrm{v})$ of $\mathrm{NaCl}$ had to be added to the medium.

Liquid to liquid transfers were made with $10 \%(\mathrm{v} / \mathrm{v})$ inocula in media that had been warmed to $37^{\circ}$. Care was taken not to shake the freshly inoculated cultures. On solid media the adapted strains grew in the characteristic L-colonies. The yield of the adapted L-strains in low-salt liquid media was inferior to that in the usual L-media and to that of non-adapted strains in their usual media. The adapted strains will be called in this paper 'low-salt' L-strains, in contrast to the non-adapted high-salt L-strains. The low-salt VB L-strain turned out to be transferable to blood agar plates, on which the colonies were macroscopically similar to those of the bacterial phase. However, less haemolysis is produced by the L-strain, and microscopic observation was necessary to disclose the characteristic morphology of an L-phase colony. Haemolysin production of the low-salt GL-8 L-strain also was less than that of the bacterial phase, and even disappeared altogether with successive transfers of this strain.

We were not able to revert the group A streptococcus L-strains adapted to low-salt media. Neither could we demonstrate $\mathrm{M}$-antigen production by the method of Freimer, Krause \& McCarty (1959). The parentage of the most interesting L-strain, the low-salt VB L-strain that grows on blood agar, was confirmed for us by determination of the DNA base composition (Hill, I968): Dr W. R. Maxted (Colindale) extracted the DNA from the L-strain and from the supposed parent strain after making labile the cell wall of the latter by means of streptomyces enzyme (McCarty, I952); Mr L. R. Hill (Colindale) determined the denaturation temperatures. Both samples of DNA were identical, with a denaturation ('melting') temperature $\left(T_{m}\right)$ of parent strain DNA $=85.3^{\circ}: \%$ GC $=$ $39^{\circ} 02$ and a $\left(T_{m}\right)$ of adapted L-strain $=85 \cdot 2^{\circ}: \% \mathrm{GC}=38 \cdot 78$.

Mice. Random-bred Swiss mice of both sexes, weighing 25 to $35 \mathrm{~g}$., were used.

\section{Homogenization of mouse organs}

The numbers of L-elements contained in various mouse organs, as a result of intravenous or intraperitoneal injection, were counted after homogenization of the organs in $4.5 \mathrm{ml}$. L-medium by means of an all glass hand-operated Potter homogenizer. Pour plates containing $15 \mathrm{ml}$. L-medium and receiving $0.5 \mathrm{ml}$. homogenate were 
incubated at $37^{\circ}$ for 5 days. In a model experiment, homogenization of L-strain suspensions together with kidney tissue did not decrease the number of colonyforming units. Therefore the homogenization procedure was considered to be innocuous for L-phase elements.

Tissues have been shown to contain inhibitors of micro-organisms (Skarnes \& Watson, 1957); when tissue cells are damaged, substances lethal for mycoplasma (Tully \& Rask-Nielsen, 1967; Kaklamanis et al. 1969) and L-elements (Minck, 1954) seem to appear. In our experiments, tissue homogenates in the dilutions cultured did not decrease the number or viable elements more than L-medium. We draw this conclusion from $105 \mathrm{~min}$. survival experiments in various dilutions of mouse tissue homogenates, using a GL- 8 L-strain that has been kept in our laboratory during more than 900 transfers on L-medium containing 3\% (w/v) NaCl. The high number of L-elements isolated from the mice in the first minute after injection (see Results) is the best indication that homogenizing mouse tissues does not seriously harm the Lphase strains.

After intraperitoneal injections, organs to be cultured were first thoroughly washed in distilled water to free them of adherent L-elements or bacteria.

Filter boxes. In some experiments the L-phase elements of group A haemolytic streptococcus strain vB were protected against phagocytosis by enclosure in boxes covered with a $220 \mathrm{~nm}$. Millipore filter. Round cover-glasses were glued with a twocomponent epoxy cement on one side of perspex rings (inner diameter Io mm., outer diameter $15 \mathrm{~mm}$., thickness $3 \mathrm{~mm}$.). After filling the box with L-elements in molten agar, Millipore filters were glued with Millipore cement on the other side of the ring. The filter boxes were implanted in the peritoneal cavity of mice, directly or after incubation in liquid L-medium and removed at various times. Removal of the opaque filters permitted high power microscopic observation of undisturbed contents.

\section{RESULTS}

\section{Intraperitoneal and intravenous injections}

Tables $I$ to 3 indicate the survival of bacterial phase elements of the three strains (table sections A), of the elements of the derived L-phase strains requiring osmotic protection (table sections B), and of the elements of the derived L-strains adapted to physiological osmotic conditions (table sections $\mathrm{C}$ ).

From table sections A it can be concluded that bacterial phase elements may persist for at least I day even when the injected dose is less than I/I000 of the lethal dose. In contrast to this, the high-salt L-phase elements of the same strains were killed within a few hours, as is shown in table sections B. Adaptation of the L-strains to physiological osmotic conditions did not enhance their survival in the animal body because low-salt L-elements also did not survive for more than a few hours, as is shown in table sections $\mathrm{C}$.

\section{Survival of $V B-L$ elements in filter boxes}

When filter boxes, inoculated with the low-salt L-strain of group A streptococcus strain VB, were first incubated in liquid L-medium for I day and then implanted in the mouse peritoneal cavity, the I-day-old L-colonies did not develop any further as did the control boxes that were kept in liquid medium. However, a few viable elements could be retrieved even after 8 days. The morphology of these small colonies was 


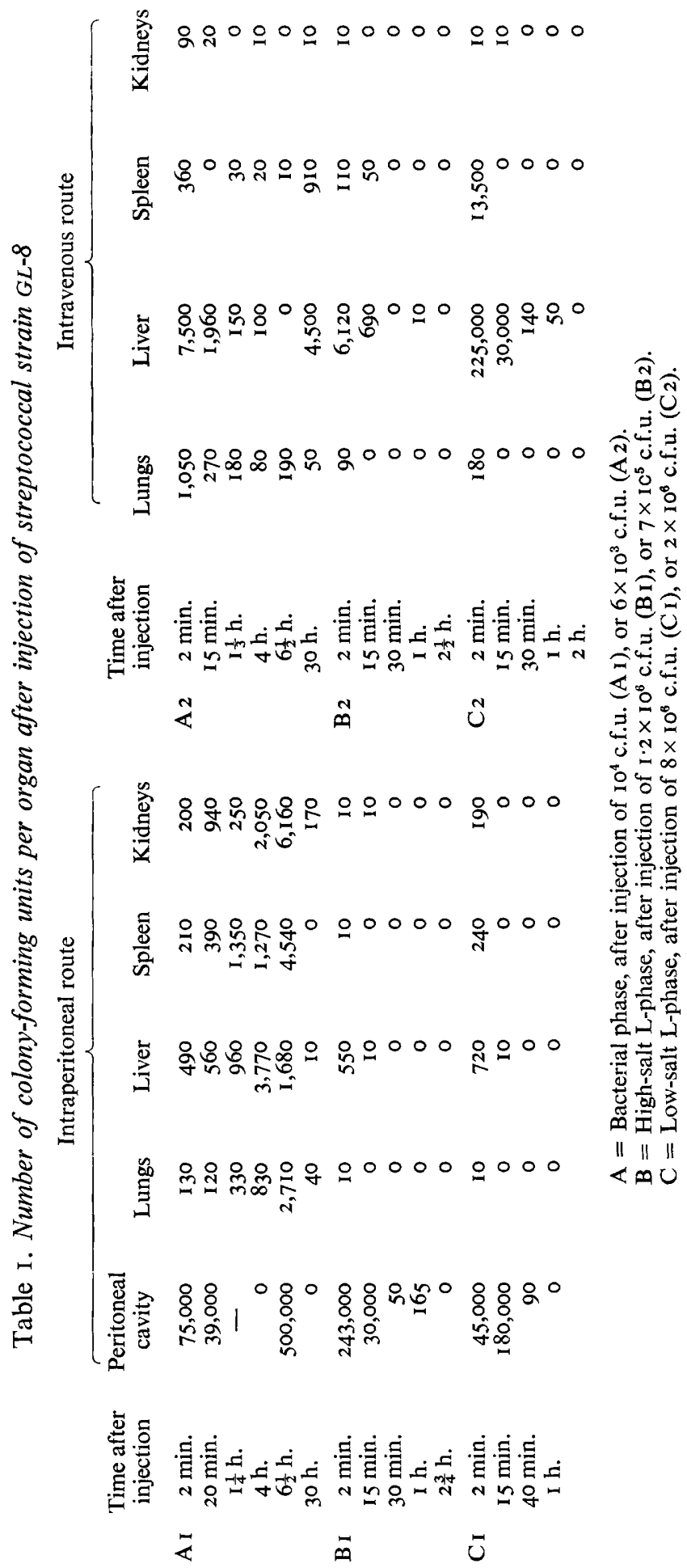




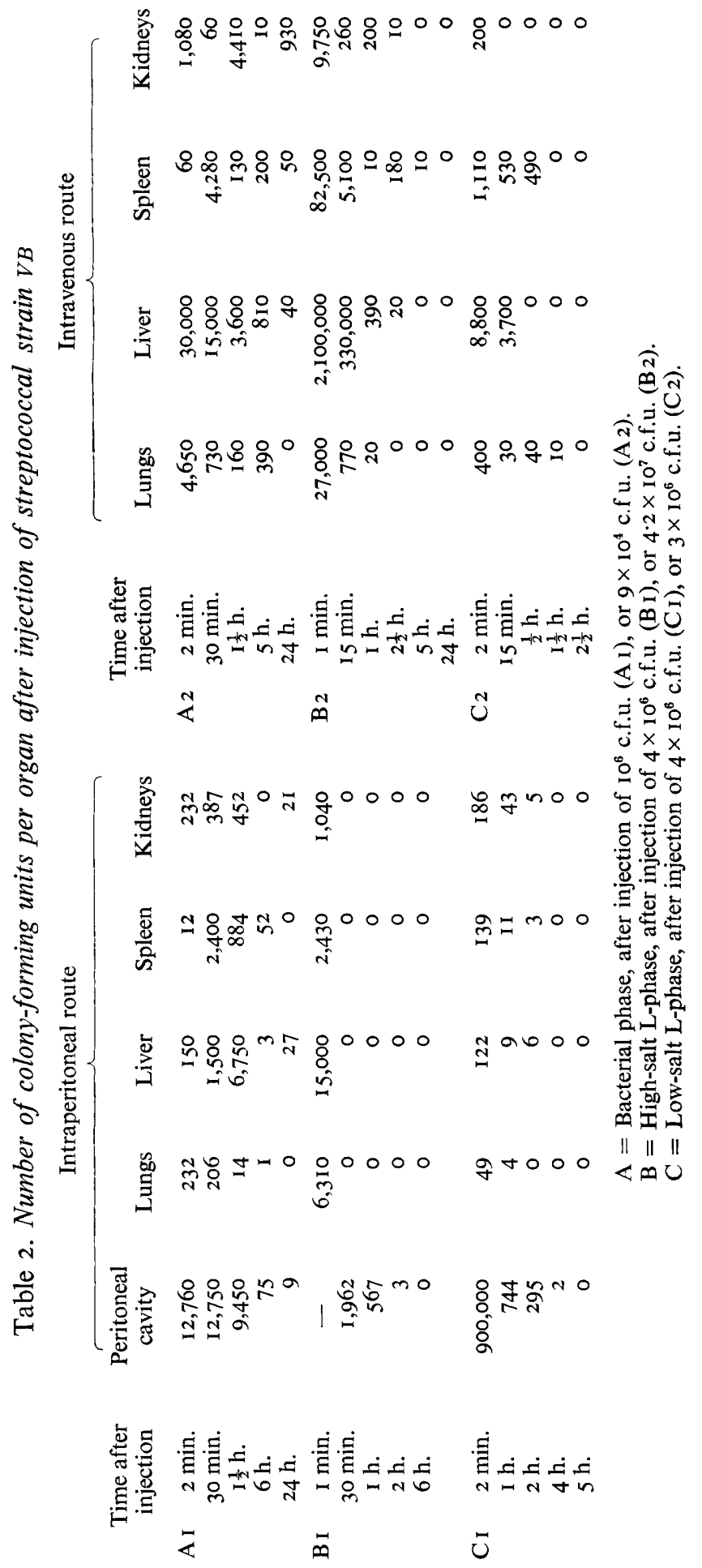




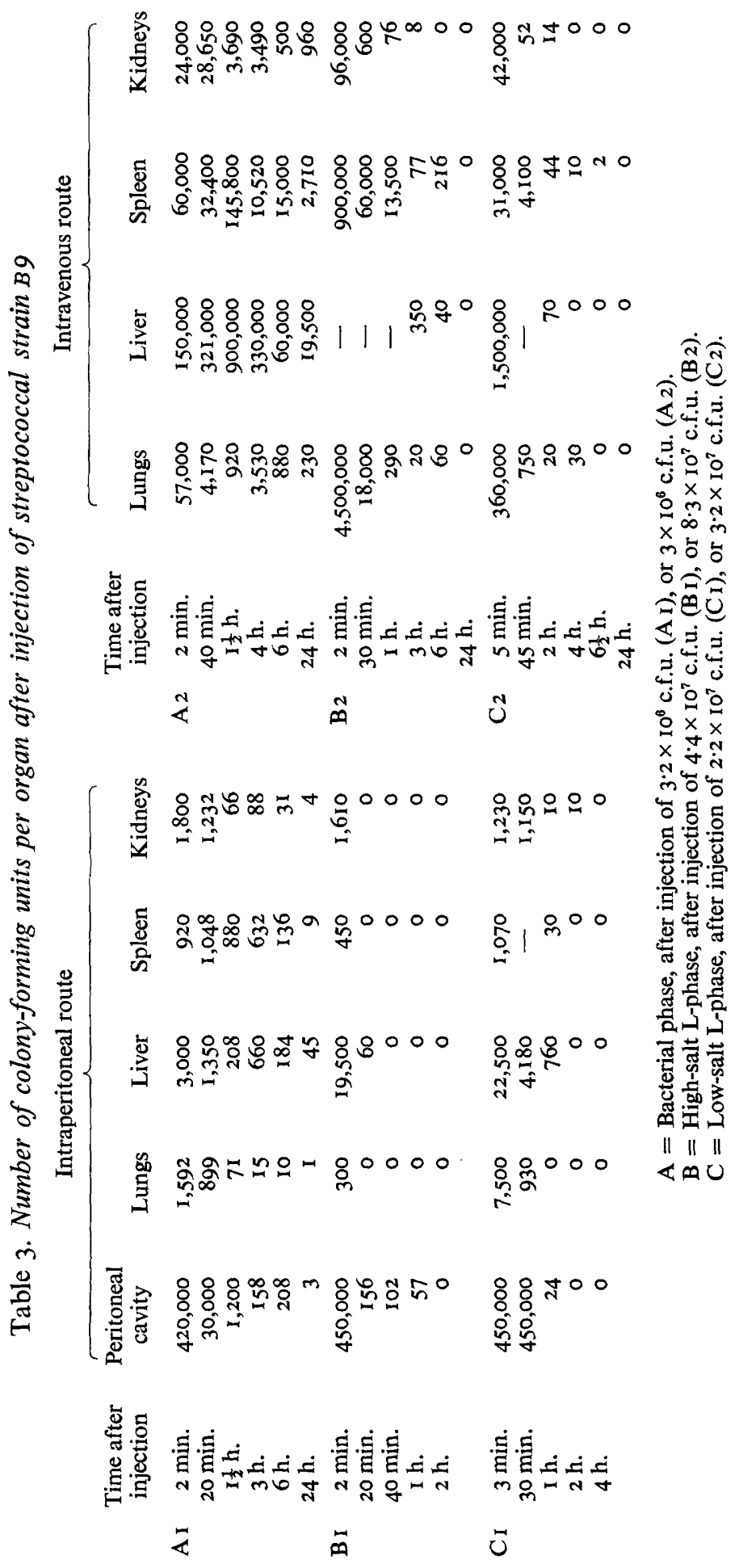


preserved too. This is in contrast to the ghost-like appearance that resulted when high-salt L-colonies were implanted intraperitoneally in filter boxes. Furthermore, viable elements could be retrieved from implanted high-salt L-colonies of this strain for only a few hours.

When filter boxes were inoculated with low-salt vB L-elements in agar and implanted without pre-incubation in liquid L-medium, no colonies developed.

\section{DISCUSSION}

The cell wall-damaging capacity of serum factors has been studied more extensively (Muschel, I968) than their action on the cell membrane, for example their lethal action on the L-phase (Kalmanson, Hubert, Montgomerie \& Guze, 1968). The action of serum on the L-phase probably depends on the strain: while the GL- 8 low-salt L-strain, protected in filter boxes, died in mice almost as fast as in distilled water (Clasener \& Ensering, 1970 $b$ ), suggesting a lethal action, the vB low-salt L-strain, in the filter box experiment described above, seemed to suffer only a bacteriostatic action from the serum as has been described for dermatophytes (Lorincz, Priestley \& Jacobs, 1958).

In preliminary experiments, we found that $20 \%$ fresh rat serum in the medium did not sustain growth of the low-salt GL- 8 L-strain in the same way as did $20 \%$ old rat serum (Seitz-filtered and stored at $-20^{\circ}$ for several weeks). Heating fresh rat serum for $20 \mathrm{~min}$. at $56^{\circ}$ did not abolish its inhibiting action, neither did addition of $12 \%$ fresh guinea-pig serum make the old rat serum inhibitory. These phenomena were observed not only on agar media that is anticomplementary, but also in liquid media. Therefore the growth-inhibiting action is not dependent on complement. Moreover, it is not a lethal action, since with longer incubation growth occurred.

We think that bactericidal action of fresh serum (Kalmanson et al. 1968) may play a role in killing some L-strains, but that serum contains bacteriostatic factors not identical to complement nor to lysozyme, which, in preliminary experiments, did not act on our L-strains.

Osmotic lability is not the only reason for the L-phase to perish in the mouse; as reported elsewhere (Clasener \& Ensering, I $970 \mathrm{~b}$ ), the GL-8 low-salt L-strain, protected in filter boxes, died in mice faster than in physiological salt solution. Furthermore, osmotic stabilization does not abolish the lethal action of serum (Kalmanson et al. I968).

In spite of these considerations, we think that the effect of phagocytosis surpasses all serum actions. This is indicated by the fact that, in the experiments described above, there is no difference in survival between the GL-8 low-salt L-strain and the vB lowsalt L-strain upon intraperitoneal or intravenous injection. In this respect it is interesting that fluorescein labelled GL-8 membranes have been found to disappear within $72 \mathrm{~h}$. after intramuscular injection of mice (Rickles et al. 1969).

We are grateful to Dr W. R. Maxted and Mr L. R. Hill (Colindale, London) for the determination of the base composition of strain vB and its L-phase.

\section{REFERENCES}

Clasener, H. A. L. \& EnSering, H. L. (1970a). Search for the L-phase of Streptococcus faecalis in kidneys of rats experimentally infected with the bacterial phase and treated with penicillin. Annals of the New York Academy of Sciences. (In Press.) 
Clasener, H. A. L. \& Ensering, H. L. (1970 $b$ ). The possible role of bacteriocins in the disappearance in vivo of the L-phase of group A haemolytic streptococci. Edited by M. Köhler. In Proceedings of the Fourth International Symposium on Streptococcus pyogenes, Jena, 29 September to 3 October 1969. (In preparation.)

Freimer, E. H., Krause, R. M. \& McCarty, M. (1959). Studies of L-forms and protoplasts of group A streptococci. Isolation, growth and bacteriological characteristics. Journal of Experimental Medicine r10, 853-874.

Guze, L. B. \& Kalmanson, G. M. (1964). Persistence of bacteria in 'protoplast' form after apparent cure of myelonephritis in rats. Science, New York 143, I340-134I.

Hijmans, W., van Boven, C. P. A. \& Clasener, H. A. L. (I969). Fundamental biology of the Lphase of bacteria. In The Mycoplasmatales and the L-phase of Bacteria. Edited by L. Hayflick. New York: Appleton Century Crofts.

HrLl, L. R. (I968). The determination of deoxyribonucleic acid base compositions and its application to bacterial taxonomy. In Identification Methods for Microbiologists, Part B. Edited by B. M. Gibbs and D. A. Shapton. London and New York: Academic Press.

KaGAN, G. Y. \& Mikhailova, V. S. (1963). Isolation of L-forms of streptococci from the blood of patients with rheumatism and endocarditis. Journal of Hygiene, Epidemiology, Microbiology and Immunology 7, 327-343. (In Russian.)

Kaklamanis, E., Thomas, L., Stravropoulos, K., Borman, I. \& Boshwitz, C. (1969). Mycoplasmacidal action of normal tissue extracts. Nature, London 221, 860-862.

Kalmanson, G. M., Hubert, E. G., Montgomerie, J. Z. \& Guze, L. B. (I968). Serum bactericidal activity against protoplasts. In Microbial Protoplasts, Spheroplasts and L-forms. Edited by L. B. Guze. Baltimore: Williams and Wilkins.

LACK, C. H. (1968). Experimental models of rheumatoid arthritis. Medical Clinics of North America $\mathbf{5 2}, 667-672$.

Lorincz, A. L., Priestley, J. O. \& JACOBS, P. H. (1958). Evidence for a humoral mechanism which prevents growth of dermatophytes. Journal of Investigative Dermatology 31, 15-17.

MCCARTY, M. (1952). The lysis of group A hemolytic streptococci by extracellular enzymes of Streptomyces albus. I. Production and fractionation of the lytic enzymes. II. Nature of the cellular substrate attacked by the lytic enzymes. Journal of Experimental Medicine 96, 555-568.

MCCARTY, M. (1964). Missing links in the streptococcal chain leading to rheumatic fever. Circulation 29, 488-493.

MincK, R. (1954). Action des broyats d'organes sur les formes L du vibrion cholérique. Compte rendu des Séances de la Société de Biologie 148, 715-717.

Muschel, L. H. (I968). The formation of spheroplasts by immune substances and the reactivity of immune substances against diverse rounded forms. In Microbial Protoplasts, Spheroplasts and L-forms. Edited by L. B. Guze, Baltimore: Williams and Wilkins.

Rickles, N., Zilberstein, Z., Kraus, S., Arad, G., Kaufstein, M. \& Ginsburg, I. (I969). Persistence of group A streptococci labelled with fluorescein isothiocyanate in inflammatory sites in the heart and muscle of mice and rabbits. Proceedings of the Society for Experimental Biology and Medicine I31, 525-530.

Schmitt-Slomska, J., Sacquet, E. \& Caravano, R. (1967). Group A streptococcal L-forms. I. Persistence among inoculated mice. Journal of Bacteriology 93, 45I-455.

SchmitT-Slomska, J. \& Mauss, H. (1968). Répartition des formes L du streptocoque du groupe A dans l'organisme de la souris après inoculation intrapéritonéale. Compte rendu hebdomadaire des Sciences, Paris 267, 380-38 I.

Schmitt-Slomska, J., Boue, A. \& Caravano, R. (I968). A carrier state in human diploid cell cultures infected with L-forms of group A streptococcus. In Current Research on Group A Streptococcus. Edited by R. Caravano. Amsterdam: Excerpta Medica Foundation.

Skarnes, R. C. \& Watson, D.W. (1957). Antimicrobial factors of normal tissues and fluids. Bacteriological Reviews 21, 273-294.

Tully, J. G. \& Rask-Nielsen, R. (1967). Mycoplasma in leukemic mice. Annals of the New York Academy of Sciences $\mathbf{1 4 3}, 345-352$.

Watson, R. F., Hirst, G. K. \& Lancefield, R. C. (I961). Bacteriological studies of cardiac tissues obtained at autopsy from eleven patients dying with rheumatic fever. Arthritis and Rheumatism 4, 74-85. 